\title{
Expression of genes involved in early cell fate decisions in human embryos and their regulation by growth factors
}

\author{
S J Kimber ${ }^{1}$, S F Sneddon ${ }^{2,3}$, D J Bloor ${ }^{1}$, A M El-Bareg ${ }^{1}$, J A Hawkhead ${ }^{4}$, A D Metcalfe ${ }^{1}$, \\ F D Houghton ${ }^{5}, \mathrm{H}$ J Leese ${ }^{4}$, A Rutherford $^{6}$, B A Lieberman $^{2,3}$ and D R Brison ${ }^{1,2,3}$ \\ ${ }^{1}$ Faculty of Life Sciences and ${ }^{2}$ Faculty of Medical and Human Sciences, University of Manchester, Manchester \\ M13 9PT, UK, ${ }^{3}$ Department of Reproductive Medicine, St Mary's Hospital, Manchester M13 OJH, UK, ${ }^{4}$ Department of \\ Biology, University of York, York YO10 5YW, UK, ${ }^{5}$ Division of Human Genetics, University of Southampton, \\ Southampton SO16 6YD, UK and ${ }^{6}$ Assisted Conception Unit, Leeds General Infirmary, Leeds LS1 3EX, UK
}

Correspondence should be addressed to S J Kimber who is now at University of Manchester, Core Technology Facility, 46 Grafton St, ManchesterM13 9NT, UK; Email: susan.kimber@manchester.ac.uk

\begin{abstract}
Little is understood about the regulation of gene expression in human preimplantation embryos. We set out to examine the expression in human preimplantation embryos of a number of genes known to be critical for early development of the murine embryo. The expression profile of these genes was analysed throughout preimplantation development and in response to growth factor (GF) stimulation.

Developmental expression of a number of genes was similar to that seen in murine embryos (OCT3B/4, CDX2, NANOG). However, GATA6 is expressed throughout preimplantation development in the human. Embryos were cultured in IGF-I, leukaemia inhibitory factor (LIF) or heparin-binding EGF-like growth factor (HBEGF), all of which are known to stimulate the development of human embryos. Our data show that culture in HBEGF and LIF appears to facilitate human embryo expression of a number of genes: ERBB4 (LIF) and LIFR and DSC2 (HBEGF) while in the presence of HBEGF no blastocysts expressed EOMES and when cultured with LIF only two out of nine blastocysts expressed $T B N$. These data improve our knowledge of the similarities between human and murine embryos and the influence of GFs on human embryo gene expression. Results from this study will improve the understanding of cell fate decisions in early human embryos, which has important implications for both IVF treatment and the derivation of human embryonic stem cells.

Reproduction (2008) 135 635-647
\end{abstract}

\section{Introduction}

The maintenance of cell pluripotency in the inner cell mass (ICM) of the blastocyst is essential for normal embryonic development and derivation of embryonic stem cells. In the early mouse embryo, we have a basic understanding of the roles of a number of genes in determining cell fate, but the same is not true for the human embryo. In particular, although it is known that human preimplantation embryos express OCT3B/4 (Abdel-Rahman et al. 1995, Hansis et al. 2000, 2001, Cauffman et al. 2005), essential for the establishment and maintenance of a pluripotent ICM population (Buehr et al. 2003), few data are available for many other genes involved in ICM pluripotency and differentiation, such as the OCT3B/4-binding partner SOX2, NANOG and FOXD3, genes that regulate ICM survival such as $T B N$ (Voss et al. 2000), or genes such as CDX2, HASH2 and EOMES that determine trophectoderm (TE) differentiation (Ralston \& Rossant 2005, Strumpf et al. 2005). Molecular analysis of human preimplantation embryos is fraught with difficulties, given their scarcity and the moral imperative for their judicious use. Several studies have been presented revealing gene expression patterns on pooled human oocytes using microarray (Zhang et al. 2007) by PCR and differential display (Goto et al. 2002) as well as PCR and SAGE (Neilson et al. 2000). Only limited microarray data are available for the developing human embryo but Adjaye et al. (2005) managed to examine pooled separated human ICMs and TE, identifying the pluripotency associated genes $N A N O G$, SOX2 and OCT3B/4 in the ICM, while Dobson et al. (2004) published microarray data on oocytes and cleavage stage embryos but did not focus on the genes investigated in this study.

Furthermore, little is understood about the influence of extrinsic factors on the expression of these genes. In many cell types, including preimplantation embryos and embryonic stem cells, development and differentiation can be regulated by peptide growth factors (GFs) and cytokines. In human embryos, blastocyst development and their attachment are stimulated by HBEGF (Martin et al. 1998, Chobotova et al. 2002), insulin-like GF-I (IGF-I; Lighten et al. 1998) and LIF (Dunglison et al. 1996). 
In the mouse, these have all also been shown to have important roles, including regulation of preimplantation development and implantation: HBEGF (Raab et al. 1996, Paria et al. 1999); stimulation of embryo cell division, metabolism and apoptosis: IGF-I (Harvey \& Kaye 1991, 1992, Kaye et al. 1992, Byrne et al. 2002, Lighten et al. 1998); and regulation of cell pluripotency and implantation: LIF (Smith et al. 1988, Stewart et al. 1992, Kimber 2005). However, the effect of such GFs on the ability of preimplantation embryos to express specific genes is little understood. In particular, their influence on transcription of genes regulating cell fate decisions has been little investigated in embryos of any species, and not at all in humans.

This lack of basic information has scientific and clinical implications for IVF treatment. Human IVF embryos show poor viability, with only an estimated $15-20 \%$ of embryos transferred in the UK resulting in a live baby (HFEA Guide to Infertility 2006/7). Human IVF embryo development is typically characterised by arrested, delayed and abnormal cell division (Hardy et al. 2002) and failure to reach the blastocyst stage. As a result, supplementation of IVF culture media with GFs has been suggested (Lighten et al. 1998, Sjoblom et al. 2005). However, this gives rise to safety concerns as overexpression of GFs such as IGF-I leads to abnormalities in development (Hardy \& Spanos 2002). GFs and cytokines have pleiotropic effects on the cell and clearly it is essential to understand the molecular mechanisms by which they alter cell fate before clinical trials of GF supplementation can be considered.

The aims of this study were to (i) characterise the expression pattern in preimplantation human embryos of key cell fate genes, including transcription factors, markers of pluripotency or differentiation, and receptors for key GFs and (ii) determine whether expression of these genes is affected by GFs known to have a role in regulating cell fate in mouse and human embryos. Using cDNA amplification to obtain maximum information from each single embryo, we aimed to obtain an informative molecular fingerprint of the preimplantation human embryo and identify potential mechanisms of GF-mediated regulation of cell fate.

\section{Results \\ Developmental expression of cell fate genes in human embryos}

We have previously established panels of cDNAs from single human preimplantation embryos: pronucleate (PN), two-cell, four-cell, eight-cell and blastocyst (Bloor et al. 2002, 2004, Metcalfe et al. 2004). In the present study, this archived developmental panel was probed for the expression of genes that regulate early cell fate decisions, in particular the establishment of ICM and TE cell lineages (Table 1). Expression of $\beta$-ACTIN was used as the minimum inclusion criterion, so this gene is not included in the tables. Figure $1 \mathrm{~A}$ is a representative ethidium bromide gel showing developmental expression of selected transcripts. The expression patterns of the genes can be characterised into those that are (a) expressed at the transcript level throughout the preimplantation period (constitutively; OCT3B/4, EIF4C, GATA6, TBN); (b) expressed following activation of the embryonic genome from the four- to eightcell onwards (NANOG, FOXD3, SOX2, ERBB4), or at the blastocyst stage (TEF4, CDX2), as well as initially from the maternal genome at the $\mathrm{PN}$ stage in the case of all but CDX2 and SOX2; (c) expressed sporadically (LIFR, EOMES) and (d) completely absent at the transcript level (HASH2, ERBB1; Table 1). Staining of blastocysts for OCT3B/4, SOX2 and NANOG protein is shown in Fig. 2, and the data are summarised in Fig. 3.

\section{GF regulation of blastocyst gene expression}

We went on to examine the expression of these cell fate genes in embryos cultured to the blastocyst stage for several days in GF-containing medium compared with embryos cultured concurrently in GF-free medium (Tables 2 and 3). Embryos were cultured in $4 \mu \mathrm{l}$ drops of MediCult Universal IVF medium supplied GF free, or the same medium supplemented with either $1.7 \mathrm{nM}$ IGF-I, $1000 \mathrm{IU} / \mathrm{ml}$ recombinant human LIF or $1 \mathrm{nM}$ HBEGF. The proportion of embryos reaching blastocyst was $\sim 22 \%$ overall and did not appear to vary with GF supplementation. However, the aim of this study was not to derive quantitative data on development and the numbers of embryos involved were too small to allow any conclusions from this.

\section{Expression of cell fate genes at the blastocyst stage}

Figure $1 \mathrm{~B}$ is a representative ethidium bromide gel showing expression of selected transcripts in blastocysts grown in GF-containing medium. The majority of the genes examined were expressed at a similar frequency in the ten blastocysts cultured in non-supplemented control medium (Table 2), compared with the three blastocysts in the developmental panel (also cultured in GF-free medium, Table 1); therefore data from all 13 blastocysts will be discussed together. Although OCT3B/4 is required for the maintenance of ICM pluripotency and was expressed in 12 out of 13 blastocysts examined, one blastocyst did not express this gene. OCT3B/4 protein could be detected in the nuclei of both ICM and TE (Fig. 2). SOX2, which associates with OCT3B/4 and is an essential binding partner for it in the regulation of a number of genes, was expressed only in 5 out of 13 blastocysts, whereas NANOG was expressed in all but one blastocyst, and FOXD3 in 7 out of 13 . SOX2 protein expression was also observed in nuclei of ICM and TE 
Table 1 Expression of cell fate genes in individual preimplantation human embryos from pronucleate to blastocyst: $+/-$ denotes gene detected/ not detected.

\begin{tabular}{|c|c|c|c|c|c|c|c|c|c|c|c|c|c|c|c|}
\hline \multirow[b]{2}{*}{ Gene } & \multicolumn{3}{|c|}{ Pronucleate } & \multicolumn{3}{|c|}{2 cell } & \multicolumn{3}{|c|}{4 cell } & \multicolumn{3}{|c|}{8 cell } & \multicolumn{3}{|c|}{ Blastocyst } \\
\hline & 1 & 2 & 3 & 1 & 2 & 3 & 1 & 2 & 3 & 1 & 2 & 3 & 1 & 2 & 3 \\
\hline ОСТЗВ/4 & + & + & + & + & + & + & + & + & + & + & + & + & - & + & + \\
\hline SOX2 & - & - & - & - & - & - & + & + & + & + & - & + & + & + & - \\
\hline NANOG & + & + & + & - & - & - & - & - & - & + & + & + & + & + & + \\
\hline FOXD3 & - & - & - & - & - & - & - & - & - & + & + & + & + & + & - \\
\hline TBN & + & + & + & + & + & + & + & + & - & + & + & + & + & + & - \\
\hline TEF4 & - & - & - & - & - & - & - & - & - & - & - & - & + & + & + \\
\hline EIF4C & + & + & + & + & + & + & + & + & + & + & + & + & + & + & + \\
\hline$C D \times 2$ & - & - & - & - & - & - & - & - & - & - & - & - & + & + & + \\
\hline HASH2 & - & - & - & - & - & - & - & - & - & - & - & - & - & - & - \\
\hline EOMES & - & + & - & - & - & - & - & - & + & + & - & - & - & - & - \\
\hline GATA6 & + & + & + & + & + & + & + & + & + & + & + & + & + & + & + \\
\hline$D S C 2^{\mathrm{a}}$ & - & - & - & - & - & - & - & - & - & - & - & - & - & + & - \\
\hline LIFR & - & + & - & - & - & - & + & - & - & - & - & - & - & - & - \\
\hline ERBB1 & - & - & - & - & - & - & - & - & - & - & - & - & - & - & - \\
\hline ERBB4 & + & + & + & - & - & - & - & - & - & + & - & + & + & + & - \\
\hline
\end{tabular}

ancluded for consistency: published in Bloor et al. (2002).

but NANOG protein was restricted to nuclei of the ICM (Fig. 2). Notably, the expression of $T B N$, which is essential to murine ICM survival, was seen in only 6 out of 13 human blastocysts. TEF4 transcripts were detected in 10 out of 13 blastocysts. EIF4C, which is associated with translation initiation, was expressed in 12 out of 13 blastocysts. Expression of HASH2 and EOMES, both associated with TE fate, was detected in
4 out of 13 and 5 out of 13 blastocysts respectively. DCS2, a structural component of desmosomes, which are assembled in murine TE at the blastocyst stage, was expressed in only 5 out of 13 blastocysts. ERBB 4 (HBEGF receptor) expression was observed in two out of the three blastocysts in the developmental panel (Table 1) but in only one of the ten GF control blastocysts (Table 2). LIFR was detected in only one blastocyst, while expression of
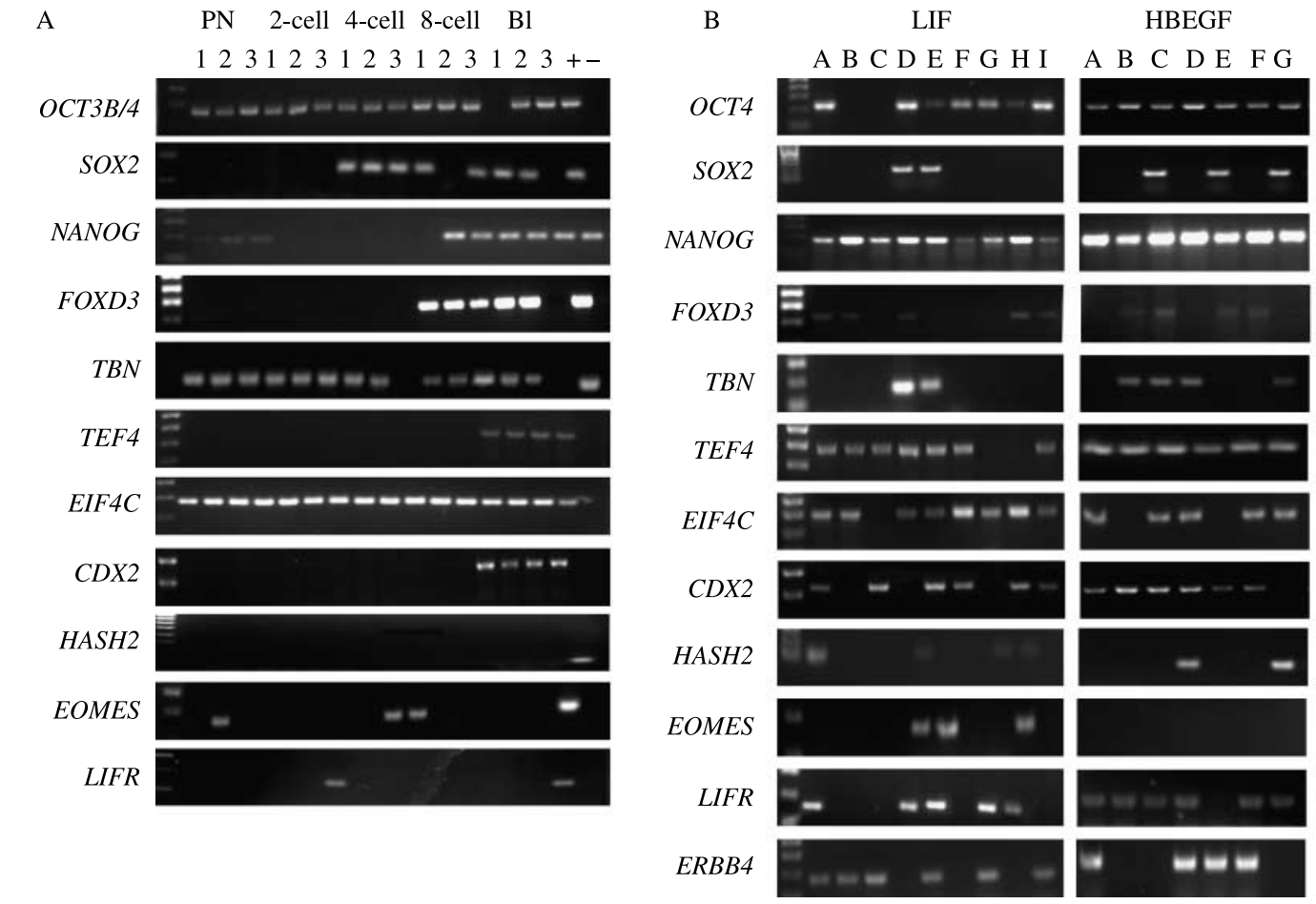

IGF-I

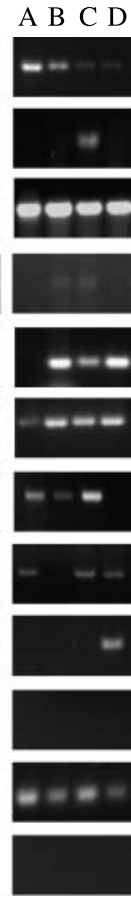

Figure 1 (A) PCR amplification of OCT3B/4, SOX2, NANOG, TBN, TEF4, EIF4C, CDX2, HASH2, EOMES, LIFR and ERBB4 from cDNAs amplified from three individual embryos at the pronucleate (PN), two-cell, four-cell, eight-cell and blastocyst stages of development. (B) PCR amplification of OCT3B/4, SOX2, NANOG, TBN, TEF4, EIF4C, CDX2, HASH2, EOMES, LIFR and ERBB4 from cDNAs amplified from embryOs grown to the blastocyst stage in growth factor-containing medium. Embryos were grown in either LIF, HBEGF or IGF-I. 


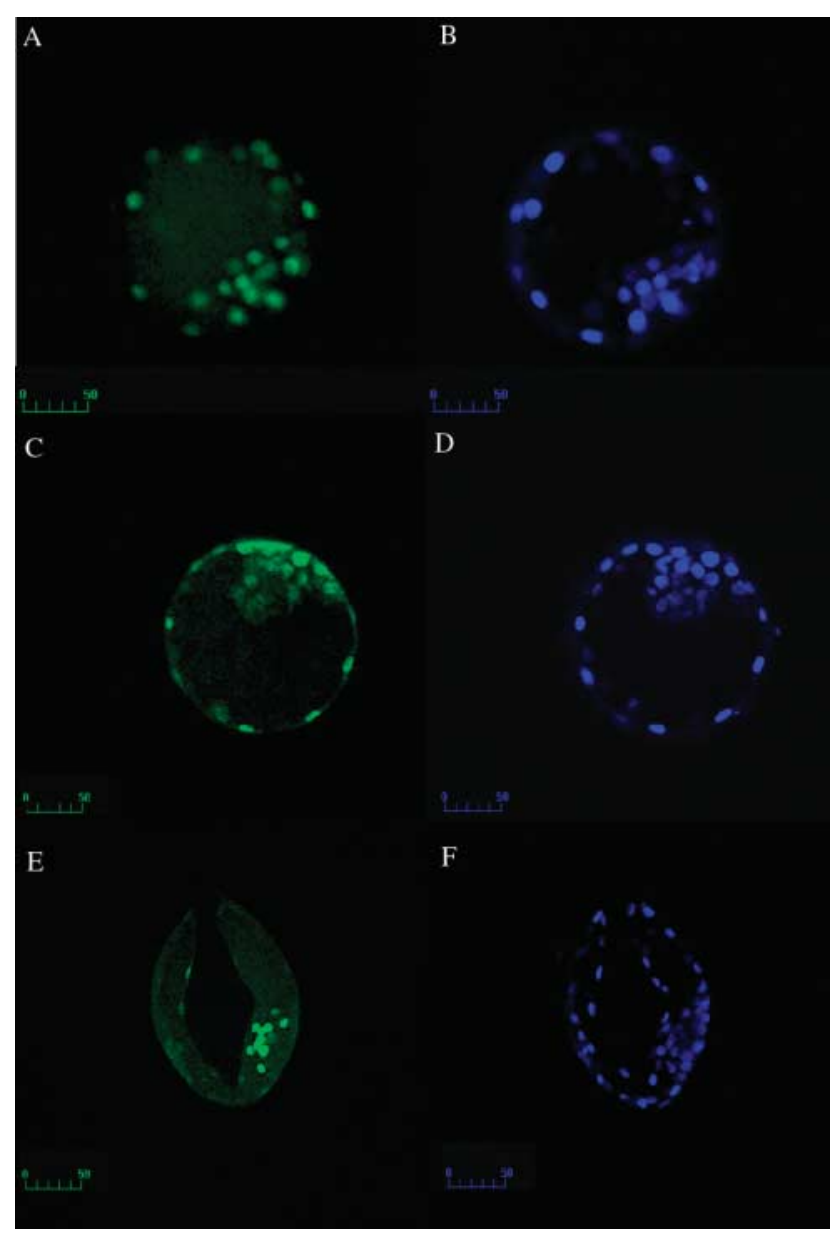

Figure 2 Confocal images of fixed human blastocysts showing protein localisation of OCT3B/4 (A), SOX2 (C) and NANOG (E) (shown in green). Nuclei are stained with DAPI, blue (B, D and F). Scale bars $=50 \mu \mathrm{m}$.

$E R B B 1$, the receptor for TGF- $\alpha$ and EGF, was not detected in any of the 13 blastocysts.

Considering the 13 genes examined in both parts of the study, overall expression was slightly higher in the developmental panel blastocysts (Table 1; mean $\sim 7.7 / 14$ genes expressed per blastocyst) compared with the GF control blastocysts (Tables 2 and 4; mean 7.2/13 genes expressed per blastocyst). Expression was quite consistent between blastocysts, with none expressing more than 10 out of the 14 genes, and only one fewer than five genes: blastocyst A of the GF control blastocysts (Table 2), which expressed only three genes including OCT3B/4.

\section{Gene expression after culture in HBEGF}

After culture in HBEGF (Fig. 1B; Table 3), 10 out of the 14 genes examined showed a very similar frequency of expression to that of the unsupplemented control blastocysts (Tables 1 and 2; data summarised in Table 4), including ERBB1 (no expression), EIF4C (5/7 compared with 12/13 controls), TBN (4/7 compared with
6/13 controls), HASH2 (2/7 compared with 4/13 controls), OCT3B/4 (7/7 compared with 12/13 controls), SOX2 (3/7 compared with 5/13 controls), NANOG (7/7 compared with $12 / 13$ controls), FOXD3 (4/7 compared with 7/13 controls) and CDX2 (6/7 compared with 11/13 controls) (Table 4). ERBB4 was expressed at a similar frequency in HBEGF (4/7) as in the developmental panel (2/3; Table 1$)$, but at a much greater frequency than in the unsupplemented control group where it could be detected in only one out of ten embryos (Table 2).

However, for three genes, striking changes in blastocyst gene expression were observed in HBEGF (Table 3) compared with unsupplemented control blastocysts (Tables 1, 2 summarised in Table 4). First, DCS2 was expressed in 5 out of 7 blastocysts in HBEGF, compared with only 5 out of 13 of the unsupplemented controls (Table 4). This was also at greater frequency than the three out of nine of the blastocysts in LIF and two out of four in IGF-I. Secondly, in the presence of HBEGF, 6 out of 7 blastocysts expressed LIFR, compared with only 1 out of 13 of the unsupplemented controls and 1 out of 4 embryos in IGF-I. Finally, TEF4 was expressed by all blastocysts (7/7) in HBEGF, compared with only 10 out of 13 controls. Considering all 14 genes, HBEGF-cultured blastocysts expressed an average of 8.6 genes per embryo, compared with 7.2 in control blastocysts (Table 4).

\section{Gene expression after culture in LIF}

After culture in LIF, most of the genes showed similar expression patterns to controls (Fig. 1B; Tables 1-3 and data summarised in Table 4), including OCT3B/4, SOX2, NANOG, FOXD3, EIF4C, HASH2, EOMES, TEF4 and $D S C 2$. ERBB1 was again not expressed.

However, notable changes were observed in the expression of three genes. LIFR was expressed in 5 out of 9 LIF-cultured blastocysts compared with 1 out of 13 controls. ERBB4 was expressed in 6 out of 9 blastocysts in LIF, compared with 3 out of 13 controls. However, TBN was detected in only 2 out of 9 LIF-cultured blastocysts but in 6 out of the 13 unsupplemented blastocysts. Considering all 14 genes, LIF-cultured blastocysts expressed an average of 7.4 genes per embryo, compared with 7.2 in control blastocysts.

\section{Gene expression after culture in IGF-I}

When IGF-I was added to the medium (Table 3), few obvious changes in the expression of the candidate genes were observed compared with controls (Tables 1 and 2, data summarised in Table 4). EOMES, ERBB4 and $E R B B 1$ were notable by their lack of expression. HASH2 and DSC2 were expressed in only two out of four embryos, similar to the controls. All four embryos expressed NANOG and OCT3B/4 but only two out of four expressed SOX2. As with blastocysts cultured in 


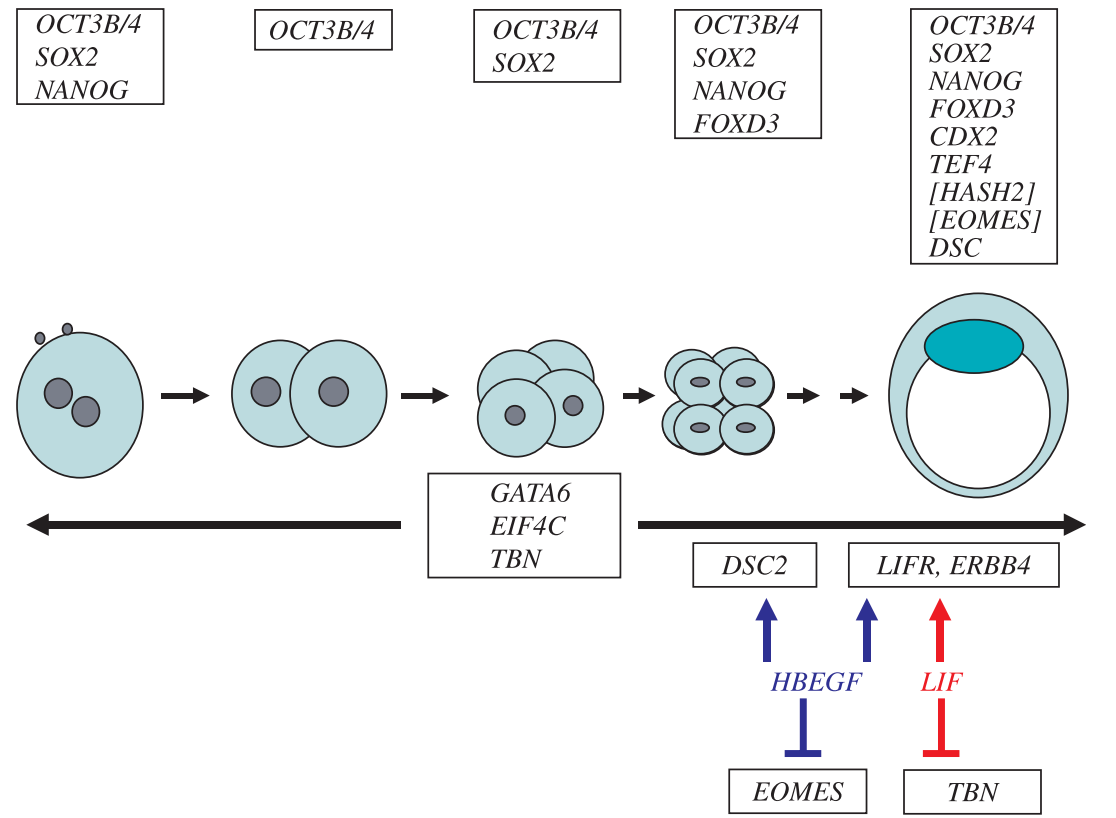

Figure 3 Diagram indicating the stage-specific or constitutive expression of genes detected in this study and the effect of growth factors. Groups of genes in boxes are expressed at the underlying stage of human preimplantation development. GATA6, EIF4C and TBN show constitutive expression over the range of stages studied. HBEGF and LIF influence the number of blastocysts expressing LIFR and ERBB4, and HBEGF those expressing $D S C 2 T B N$ and (negatively) EOMES.
HBEGF, embryos cultured in IGF-I all expressed TEF4 but this was not dissimilar to the 10 out of 13 unsupplemented control blastocysts. Three-quarters of the blastocysts expressed TBN, compared with 6 out of 13 controls and the 2 out of 9 embryos cultured in LIF. Considering all 14 genes, IGF-I-cultured blastocysts expressed an average of 8.0 genes per embryo, compared with 7.2 genes per control blastocyst.

\section{Discussion}

Although we have considerable knowledge of changes in gene expression patterns during preimplantation embryo development in the mouse, much less is known about these changes in the human. Several groups have attempted to address this by examining expression of various gene families including cell adhesion molecules (Bloor et al. 2002, Ghassemifar et al. 2003), components of the apoptotic cascade (Jurisicova \& Acton 2004, Metcalfe et al. 2004), connexins (Bloor et al. 2004), as well as the totipotency/pluripotency-related transcription factor OCT3B/4 (Hansis et al. 2000, 2001, Huntriss et al. 2002, Cauffman etal. 2005) and SOX2 (Adjaye et al. 2005). Some more extensive studies of gene expression have been attempted, for instance Adjaye et al. (2005) compared expression of genes in pooled human ICMs and TE using microarray analysis while individual oocytes and early cleavage stages were subject to microarray by Dobson et al. (2004).

GFs expressed by the reproductive tract or by the embryo itself (Schafer-Somi 2003) could exert paracrine

Table 2 Expression of genes in individual human blastocysts cultured in media lacking growth factors (non-supplemented controls): $+/-$ denotes gene detected/not detected.

\begin{tabular}{|c|c|c|c|c|c|c|c|c|c|c|c|}
\hline \multirow[b]{2}{*}{ Gene } & \multicolumn{10}{|c|}{ Blastocyst } & \multirow[b]{2}{*}{ Total } \\
\hline & A & B & $\mathrm{C}$ & $\mathrm{D}$ & $\mathrm{E}$ & $\mathrm{F}$ & G & $\mathrm{H}$ & I & $J$ & \\
\hline ОСТЗВ/4 & + & + & + & + & + & + & + & + & + & + & $10 / 10$ \\
\hline SOX2 & - & - & - & - & - & - & - & + & + & + & $3 / 10$ \\
\hline NANOG & + & + & + & + & + & + & + & + & + & - & $9 / 10$ \\
\hline FOXD3 & - & + & + & - & - & - & + & + & + & - & $5 / 10$ \\
\hline TBN & - & + & - & - & + & - & + & + & - & - & $4 / 10$ \\
\hline TEF4 & - & + & + & + & - & + & + & + & - & + & $7 / 10$ \\
\hline EIF4C & + & - & + & + & + & + & + & + & + & + & $9 / 10$ \\
\hline$C D \times 2$ & - & + & + & + & - & + & + & + & + & + & $8 / 10$ \\
\hline $\mathrm{HASH} 2$ & - & + & + & - & - & - & + & - & + & - & $4 / 10$ \\
\hline EOMES & - & + & + & + & - & - & + & - & - & + & $5 / 10$ \\
\hline$D S C 2$ & - & - & - & - & + & + & + & - & + & - & $4 / 10$ \\
\hline LIFR & - & - & - & - & - & - & - & - & - & + & $1 / 10$ \\
\hline ERBB1 & - & - & - & - & - & - & - & - & - & - & $0 / 10$ \\
\hline ERBB 4 & - & - & - & + & - & - & - & - & - & - & $1 / 10$ \\
\hline
\end{tabular}


Table 3 Expression of genes in individual human blastocysts cultured in media containing HBEGF, LIF and insulin-like growth factor-I (IGF-I): +/ denotes gene detected/not detected.

\begin{tabular}{|c|c|c|c|c|c|c|c|c|c|c|c|c|c|c|c|c|c|c|c|c|}
\hline \multirow{2}{*}{$\begin{array}{l}\text { Target } \\
\text { gene }\end{array}$} & \multicolumn{9}{|c|}{ LIF } & \multicolumn{7}{|c|}{ HBEGF } & \multicolumn{4}{|c|}{ IGF-I } \\
\hline & A & $\mathrm{B}$ & C & D & $\mathrm{E}$ & $\mathrm{F}$ & G & $\mathrm{H}$ & I & A & B & C & D & $\mathrm{E}$ & $\mathrm{F}$ & G & A & B & $\mathrm{C}$ & $\mathrm{D}$ \\
\hline ОСТЗВ/4 & + & - & - & + & + & + & + & + & + & + & + & + & + & + & + & + & + & + & + & + \\
\hline SOX2 & - & - & - & + & + & - & - & - & - & - & - & + & - & + & - & + & - & - & + & - \\
\hline NANOG & + & + & + & + & + & + & + & + & + & + & + & + & + & + & + & + & + & + & + & + \\
\hline FOXD3 & + & + & - & + & - & - & - & + & + & - & + & + & - & + & + & - & - & + & + & - \\
\hline$T B N$ & - & - & - & + & + & - & - & - & - & - & + & + & + & - & - & + & - & + & + & + \\
\hline TEF4 & + & + & + & + & + & + & - & - & + & + & + & + & + & + & + & + & + & + & + & + \\
\hline EIF4C & + & + & - & + & + & + & + & + & + & + & - & + & + & - & + & + & + & + & + & - \\
\hline$C D \times 2$ & + & - & + & - & + & + & - & + & + & + & + & + & + & + & + & - & + & - & + & + \\
\hline HASH2 & + & - & - & - & + & - & - & + & + & - & - & - & + & - & - & + & - & - & - & + \\
\hline EOMES & - & - & - & - & + & + & - & - & + & - & - & - & - & - & - & - & - & - & - & - \\
\hline DSC2 & + & - & - & - & + & - & - & + & - & - & + & + & - & + & + & + & - & + & + & - \\
\hline LIFR & + & - & - & - & + & + & - & + & + & + & + & + & + & - & + & + & + & + & + & + \\
\hline ERBB1 & - & - & - & - & - & - & - & - & - & - & - & - & - & - & - & - & - & - & - & - \\
\hline$E R B B 4$ & + & + & + & - & + & - & + & - & + & + & - & - & + & + & + & - & - & - & - & - \\
\hline
\end{tabular}

or autocrine effects on development. Indeed, several factors promote human blastocyst formation in vitro, such as LIF (Dunglison et al. 1996), HBEGF (Martin et al. 1998) and IGF-I (Lighten et al. 1998). However, despite much discussion about using GFs in clinical IVF, little is known of their mechanisms of action on the human embryo. We have addressed the possibility that these factors exert their effects at least in part by modulating expression of genes in the developing embryo, as in other cell types (e.g. Liu et al. 2003, Sherwin et al. 2004, Tan et al. 2004, Graham et al. 2005, Sekkai et al. 2005, Sarfstein \& Werner 2006). To investigate this, we established a baseline pattern of gene expression in a representative panel of embryos at different stages of development up to blastocyst. A summary of the stagerelated gene expression patterns obtained is shown in Fig. 3. We then examined whether the expression frequency of these genes changes in response to GF stimulation. Our original developmental panel of embryos were cultured in groups in $200 \mu \mathrm{l}$ drops (Table 1), while the later cultured embryos for the GF comparison (Tables 2 and 3) were cultured singly in $4 \mu \mathrm{l}$ drops. Autocrine factors produced by human embryos may promote development, so this difference might contribute to changes in gene expression. However, when we compared the three blastocysts in the developmental series with the ten blastocysts controls for the GF panel, the particular genes expressed were similar and overall expression was very slightly higher in the former: mean $\sim 7.7 / 14$ genes expressed per blastocyst, compared with the latter: mean 7.2/13 genes expressed per blastocyst. Thus, we could detect no obvious difference between the two culture protocols.

Table 4 Summary of blastocyst gene expression in the absence and presence of growth factors ( $\beta$-ACTIN and ERBB1 excluded).

\begin{tabular}{|c|c|c|c|c|}
\hline Data source & $\begin{array}{l}\text { No growth factor } \\
\text { Tables } 1 \text { and } 2\end{array}$ & $\begin{array}{l}\text { HBEGF } \\
\text { Table } 3\end{array}$ & $\begin{array}{c}\text { LIF } \\
\text { Table } 3\end{array}$ & $\begin{array}{l}\text { IGF-I } \\
\text { Table } 3\end{array}$ \\
\hline \multicolumn{5}{|l|}{ Gene } \\
\hline ОСТЗВ/4 & $12 / 13$ & $7 / 7$ & $7 / 9$ & $4 / 4$ \\
\hline SOX2 & $5 / 13$ & $3 / 7$ & $2 / 9$ & $2 / 4$ \\
\hline NANOG & $12 / 13$ & $7 / 7$ & $9 / 9$ & $4 / 4$ \\
\hline FOXD3 & $7 / 13$ & $4 / 7$ & $5 / 9$ & $2 / 4$ \\
\hline$T B N$ & $6 / 13$ & $4 / 7$ & $2 / 9$ & $3 / 4$ \\
\hline TEF4 & $10 / 13$ & $7 / 7$ & $7 / 9$ & $4 / 4$ \\
\hline EIF4C & $12 / 13$ & $5 / 7$ & $8 / 9$ & $3 / 4$ \\
\hline$C D \times 2$ & $11 / 13$ & $6 / 7$ & $6 / 9$ & $3 / 4$ \\
\hline $\mathrm{HASH} 2$ & $4 / 13$ & $2 / 7$ & $4 / 9$ & $1 / 4$ \\
\hline EOMES & $5 / 13$ & $0 / 7$ & $3 / 9$ & $0 / 4$ \\
\hline$D S C 2$ & $5 / 13$ & $5 / 7$ & $3 / 9$ & $2 / 4$ \\
\hline LIFR & $1 / 13$ & $6 / 7$ & $5 / 9$ & $4 / 4$ \\
\hline ERBB4 & $3 / 13$ & $4 / 7$ & $6 / 9$ & $0 / 4$ \\
\hline Genes expressed/blastocyst & $7.2^{\mathrm{a}}$ & 8.6 & 7.4 & 8 \\
\hline
\end{tabular}

a 7.0 concurrent controls only, 7.2 including blastocysts from developmental series (Table 1). 


\section{Developmental expression of genes}

Expression of OCT3B/4, a marker of pluripotency expressed throughout murine and human preimplantation development (Rosner et al. 1990, Palmieri et al. 1994, Hansis et al. 2000, Pesce \& Scholer 2001), was detected throughout development in our study as well. In mouse, it becomes restricted to the ICM (Palmieri et al. 1994, Mitalipov et al. 2003), while in the human, OCT3B/4 is also expressed in the TE (Hansis et al. 2000 and this study). However, nuclear expression of OCT3B/4 was stronger in ICM cells and a dosage effect is possible as seen in experimental studies in murine ES cells (Niwa et al. 2000). Cytoplasmic expression may suggest a slow turnover of mRNA synthesised but not translocated to the nucleus to regulate gene function. Sox2 co-operates with Oct $3 b / 4$ in positively regulating Fgf4 (Ambrosetti et al. 2000), Utf1 (Nishimoto et al. 1999) and Nanog (Kuroda et al. 2005, Rodda et al. 2005), as well as both Sox2 and Oct3b/4 themselves (Tomioka et al. 2002, Okumura-Nakanishi et al. 2005) in mouse ES cells. The importance of this gene is suggested from a recent study indicating that OCT3B/4, SOX2 and NANOG together bind the promoter region and are assumed to regulate 353 genes in human ES cells (Boyer et al. 2005).

In murine embryos, transcripts were detected first at the morula stage and then in the blastocyst ICM, however, protein was detected throughout preimplantation development (Avilion et al. 2003). Human zygotic transcription is initiated around the early four-cell stage (Braude et al. 1988) when only very weak signals were detected for SOX2, except in one embryo, suggesting onset of SOX2 transcription around this time. At the eight-cell to blastocyst stage, two out of three of embryos were positive for $S O X 2$ expression. It is possible that the numbers of expressing cells and hence the number of transcripts was below the level of detection in some embryos. Surprisingly, in our control series for the GF cultures, we were not able to pick up SOX2 transcripts in many $O C T 3 B / 4$ and NANOG-positive blastocysts. Signals that normally maintain SOX2 expression may be missing in the GF-free medium or in microdrop culture. Protein expression in both human ICM and TE may reflect a later stage in development than in the murine blastocyst TE epithelium where SOX2 is found only in cytoplasm (M Keramari, J Razavi, KA Ingman, CM Ward \& SJ Kimber, unpublished data) but later expressed in extraembryonic ectoderm (Avilion et al. 2003). SOX2 transcripts were also detected in pooled human ICMs in another study (Adjaye et al. 2005), but variation between embryos could not be assessed. In mouse embryos, it has been suggested that Sox 2 mRNA expression is closely related to developmental potential (Li et al. 2005). The crucial role for Sox2 in mouse embryonic stem (ES) cells is suggested to be the stabilisation of the pluripotent state by maintaining the required level of Oct4 expression (Masui et al. 2007).
The combination of four genes: Sox2, Oct4, c-myc and $K I f 4$, allowed formation of pluripotent stem cells from mouse embryonic and adult fibroblasts (Takahashi et al. 2007). That SOX2 was one of the least consistently expressed genes examined suggests that it is susceptible to being misregulated as a result of genetic or environmental factors. The heterogeneity in expression of SOX2 in our embryo panel suggests that this gene should be investigated as a possible sensitive marker of developmental potential in the human.

NANOG is specifically expressed in pluripotent stem cells in both mouse and human (Chambers et al. 2003, Mitsui et al. 2003, Bhattacharya et al. 2004, Richards et al. 2004, Hatano et al. 2005). Oct3b/4 and Nanog appear to act in concert to maintain self-renewing murine ES lines but it is now clear that transcription of Nanog is regulated directly by Oct3b/4/Sox2 (Kuroda et al. 2005, Rodda et al. 2005). NANOG mRNA inherited from the oocyte is present at the PN stage, and later, following activation of the embryonic genome, from the eight-cell stage onwards. This is earlier than that reported for mouse embryos (Chambers et al. 2003, Mitsui et al. 2003), which is intriguing in view of blastocyst formation occurring at a considerable range of cell numbers for human embryos in vitro. NANOG was expressed in all but one of the blastocysts studied and protein is restricted to ICM confirming a previous report of transcript expression in ICM but not TE (Adjaye et al. 2005) and consistent with an essential role in maintaining the pluripotent status of the human ICM.

Gata6 is expressed in the ICM of murine blastocysts and is essential for survival past the blastocyst stage (Koutsourakis et al. 1999). Studies in murine ES cells suggest that Gata6 is an essential factor for formation of the primitive (extraembryonic) endoderm (Li et al. 2004), and it has been suggested that expression of Gata6 leads to downregulation of Nanog and consequent commitment to primitive endoderm, while expression of Nanog results in downregulation of Gata6 and maintenance of the core ES cell population (Ralston \& Rossant 2005). GATA6 was constitutively expressed in preimplantation human embryos and any role during cleavage is undefined. Since NANOG mRNA is not expressed until the eight-cell stage, the opposing function of these two transcription factors could also operate in the human from the eight-cell to blastocyst stage but must be initiated by NANOG and not GATA6 expression.

FOXD3, a forkhead box winged helix transcription factor implicated in early cell fate decisions (Hanna et al. 2002), is developmentally regulated, with expression from the eight-cell stage that assumes initiation from the human zygotic genome. This would be consistent with a role in the maintenance of the stem cell population in human as has been suggested from murine Foxd3 knockout data. Foxd3 null embryos die at d6.5 after implantation, and the epiblast is not maintained while the extraembryonic 
ectoderm generates only giant cells. Alone, Foxd3 activates endoderm promoting forkhead box transcription factors, but in conjunction with Oct3b/4 repression of endoderm promoting genes occurs (Guo et al. 2002). We examined both TEF4, which is implicated in transcriptional initiation and regulation in the murine embryo (Kaneko \& DePamphilis 1998) and the translation initiation factor EIF4C (also called EIF1A). Although transcription of EIF4C in bovine and murine embryos is transiently initiated on activation of the zygotic genome (De Sousa et al. 1998), it appears to be constitutively expressed during human preimplantation development suggesting other factors may be rate limiting for translation of new mRNAs. Alternatively, quantitative changes in transcript or protein levels may regulate initiation of new translation. TEF4 was only expressed at the blastocyst stage, and in almost all blastocysts examined suggesting a role only from this stage in human, in contrast to mouse embryos. TBN is essential for the survival of the ICM in mouse embryos (Voss et al. 2000). This gene was constitutively expressed throughout human preimplantation development but showed variable expression between blastocysts. By analogy with the mouse, this might be indicative of poor blastocyst viability.

Expression of LIFR in pooled human embryos has been reported (Sharkey et al. 1995), but our study suggests expression frequency is low during preimplantation development. Given the apparent stimulation of human embryo development by LIF (Dunglison et al. 1996), this is surprising. However, the role of the LIF signalling pathway in early human development is uncertain as it is not sufficient to maintain pluripotency in human ES cells (Humphrey et al. 2004).

Several genes implicated in TE differentiation were assessed including CDX2, EOMES and HASH2. Cdx2 is essential for development of murine trophoblast and in $C d \times 2$ knockout mice, the TE epithelium fails to be maintained (Strumpf et al. 2005). Indeed in murine ES cells, forced expression of $C d \times 2$ or downregulation of Oct3b/4 induces differentiation to TE (Niwa et al. 2005). A reciprocal inhibition between $O c t 3 b / 4$ and $C d x 2$ has been suggested to function in the divergence of the outer Cdx2-positive TE cells from the inner Oct3b/4-positive ICM stem cells. In the present study, almost all of the blastocysts cultured in unsupplemented media expressed CDX2 but no earlier stages, suggesting CDX2 is also a useful human TE marker. EOMES, expressed later by $\mathrm{TE}$, showed a sporadic expression pattern in the developmental panel of embryos, being detected in one PN embryo, one out of four-cell and one out of eight-cell and in three of the unsupplemented GF control blastocysts. Although like CDX2, HASH2 expression was not observed in any of the three developmental panel blastocysts examined, transcripts were seen in four out of ten of the unsupplemented control blastocysts suggesting these blastocysts may have trophoblast stem cell potential. Intriguingly, with the exception of one blastocyst, when CDX2 is not expressed, HASH2 and EOMES are also not expressed. This is consistent with EOMES and HASH2 being downstream of $C D X 2$ in human trophoblast development, as in mouse (Cross 2000). The lack of expression of HASH2 and EOMES in the blastocysts from the developmental panel may suggest these are at an earlier developmental stage than some of those in unsupplemented medium, which express these TE development genes. Interestingly, HAND1 that regulates giant cell differentiation in mice was expressed from the four-cell in human (Knofler et al. 2002).

Although ERBB4, the receptor for HBEGF, was expressed from the eight-cell stage onwards, expression in blastocysts was sporadic. ERBB4 protein expression in human blastocysts is important in initial attachment to the luminal epithelium (Chobotova et al. 2002) as has also been suggested in the murine embryo (Raab et al. 1996). ERBB1, the receptor for TGF- $\alpha$ and EGF, was not detected at any stage of preimplantation development nor in response to the three GFs in agreement with others (Chobotova et al. 2002).

\section{GF regulation of genes}

HBEGF is associated with improved human preimplantation development (Martin et al. 1998) and our data suggest that it may act, in part by influencing expression of genes such as LIFR, DSC2 and ERBB4. HBEGF exposed blastocysts expressed our panel of genes more frequently than control embryos or those cultured in LIF or IGF-I. The major effect of HBEGF appears to be on TE. HBEGF enhanced the number of embryos that express DSC2 compared with control and LIF-treated embryos. DSC2 is the rate-limiting protein whose presence promotes desmosome assembly in mature murine TE and has been suggested to function similarly in human (Bloor et al. 2002, Ghassemifar et al. 2003), HBEGF may influence maturation of the TE epithelium. By contrast, $C D X 2$ is expressed in the absence of HBEGF and this GF had no effect on the frequency of expression of EOMES or HASH2 either, suggesting that it influences genes regulating the epithelial phenotype rather than those involved in specification. Indeed, it appears that HBEGF may have a negative effect on EOMES expression as this gene was not expressed in any blastocyst cultured with HBEGF. $E R B B 4$, the receptor for HBEGF, was expressed sporadically in the absence of GFs, but in the majority of blastocysts exposed to HBEGF or LIF. LIFR transcripts, on the other hand, could be detected rarely (one blastocyst) in the absence of GFs but in all blastocysts (bar one) exposed to HBEGF. This confirms the potentially important role of HBEGF in regulating embryonic cells via its own and the LIF signalling pathways and that HBEGF may enhance the embryonic response to LIF. The reciprocal stimulation of expression of $E R B B 4$ by LIF, and 
LIFR by HBEGF, suggests that in vivo when embryos are exposed to the full repertoire of GFs, both of these pathways will be active. Moreover, if the LIF signalling pathway is important in regulating human embryo development (Dunglison et al. 1996), it may be that expression of LIFR in utero is normally induced by external factors, e.g. by HBEGF. At the same time, HBEGF stimulates murine TE differentiation (Das et al. 1994, Wang et al. 2000) and human blastocyst expansion (Chobotova et al. 2002). The protein is mobilised to the cell surface of murine blastocysts by lysophosphatidic acid that accelerates differentiation by transactivation of Erbb1 and Erbb4 (Liu \& Armant 2004).

Although frequency of expression of most genes were unaffected by LIF, several notable changes were observed. ERBB4 was expressed in few unsupplemented blastocysts (and none of those cultured with IGF-I) but in six out of nine cultured in LIF. Therefore, our data suggest that LIF might promote blastocyst attachment and implantation through facilitating upregulation of embryonic ERBB4, a previously unrecognised role of embryonic LIF signalling, unconnected with pluripotency. The absence of detectable LIFR transcripts in all but one control embryo is in contrast to its expression in five out of nine LIF-cultured embryos suggesting low constitutive levels of maternal LIFR protein and autoregulation.

This work has utilised archival embryo cDNA (Bloor et al. 2002) together with a new cDNA panel from GF-cultured embryos to document developmental expression of key genes associated with embryonic cell behaviour and fate. In addition, although the numbers of embryos available for experimental purposes were by necessity limited, we believe that our data demonstrate for the first time evidence of mechanisms by which GFs may alter human embryo cell fate and stimulate developmental potential. Embryos that do not express particular genes in response to a particular GF may be at the incorrect developmental stage to be able to respond appropriately, or may be deficient in the receptor or downstream signalling pathways. In general, LIF and HBEGF appear to have a positive influence mainly on transcripts for structural or receptor genes involved in TE maturation and function. This is consistent with GF regulation of human embryo development at least in part by the stimulation of gene transcription and suggests areas for future investigation, such as cross talk between different GF pathways. It provides a developmental baseline from which to launch and interpret studies examining GF-regulated pathways in human ES cells and to determine which GFs could be used to improve clinical IVF treatment. Since some commercially available embryo culture media already contain GFs and others are currently under clinical trial, there is an urgent need to understand the basis of their influence on the human embryo.

\section{Materials and Methods}

All reagents were purchased from Sigma, unless otherwise stated.

\section{Embryos}

Human embryos were donated to research after patient consent, with approval of local ethics committees and the UK Human Fertilisation and Embryology Authority (Research licences R0026 and R0067). Embryos were obtained from IVF units at St Mary's Hospital, Manchester; Manchester Fertility Services, Manchester (from frozen embryos surplus to IVF requirement for the developmental series, Table 1; Fig. 1) and Leeds General Infirmary, Leeds (fresh embryos for the GF studies, Tables 2 and 3), as in our previous studies (Bloor et al. 2002, 2004, Metcalfe et al. 2003, 2004). Embryos were cultured to various developmental stages in $200 \mu \mathrm{l}$ drops of MediCult Universal IVF medium (MediCult UK Ltd, Redhill, Surrey, UK) for the data in Table 1 and Fig. 1. Alternatively, they were cultured in $4 \mu$ drops of optimised embryo culture medium developed at the University of York (Houghton et al. 2002, Brison et al. 2004) for the data in Tables 2 and 3, either in the absence of any GFs or cytokines (control; MediCult Universal IVF medium supplied GF free) or in the presence of $1.7 \mathrm{nM}$ IGF-I, $1000 \mathrm{IU} / \mathrm{ml}$ recombinant human LIF or $1 \mathrm{nM}$ HBEGF. Embryos were cultured in GFs or control medium from the four- to eight-cell stage on days 2-3 of development, to the blastocyst stage on day 5 or 6 .

cDNAs from three embryos at each stage of development were probed for gene expression, as described by Bloor et al. (2002). Early cleavage stage embryos were of the highest possible quality since they were cultured from unselected frozen PN stage embryos. All the PN, two-cell and four-cell embryos were from pregnant cycles (i.e. had sibling embryos that developed to term). One out of the eight-cell embryos was from a pregnant cycle, while the two other eight-cell embryos were siblings from a cycle that did not result in pregnancy. However, the donating parents later achieved a spontaneous pregnancy. Polypronucleate embryos were not used in this study (Houghton et al. 2002).

\section{Lysis, $3^{\prime} C D N A$ generation and $2^{\circ}$ amplification (polyA PCR)}

Embryo lysis, cDNA generation and subsequent $2^{\circ}$ amplification was performed as reported by Bloor et al. (2002) and adapted from Brady \& Iscove (1993), Nunez et al. (2000) and has been extensively validated (Brady et al. 1995, Al-Taher et al. 2000, Iscove et al. 2002). The technique utilises a limited RT step to restrict the first strand to around 500-600 bases at the $3^{\prime}$ end. This is followed by dt tailing and amplification of the 500-600 bp duplexes. PCR amplification of the polyA-tailed cDNA is then carried out as described previously (Bloor et al. 2002, Metcalfe et al. 2004). Because of the restricted RT step, the amplified product does not suffer from the bias against long or rare transcripts inherent in full-length amplification schedules.

Controls at each step included embryos lysed and subjected to the amplification protocol without reverse transcriptase (RT negatives) and no embryo. Human RNA from a variety of tissues 
(Human total RNA master panel II; BD Biosciences, Oxford, UK) was amplified using the same protocol to produce positive control cDNA. Negative and positive control samples were probed for the presence of target genes in tandem with test samples.

\section{Normalisation of amplified cDNA}

Serial dilutions of secondary amplification products were prepared and used as templates in a PCR to amplify $\beta$-ACTIN as in Bloor et al. (2002). $\beta$-ACTIN has been shown previously by us to be a good reference gene for human embryos and more recently by Willems et al. (2006) in the murine embryo in a different context.

\section{Gene-specific PCR}

Primers were designed to amplify target genes in $500 \mathrm{bp}$ immediately preceding the polyadenylation signal. Primers were designed using PRIMER version 0.5 (Copyright 1991, Whitehead Institute for Biomedical Research, www.bioinformatics.nl/cgibin/primer3plus/primer3plus.cgi). Primer sequences (Invitrogen) used are shown in Table 5. Target gene amplification was performed exactly as described in Bloor et al. (2002). Absence of a gene was verified by amplification up to 50 cycles. Amplification products were partially sequenced as reported previously (Bloor et al. 2002, 2004). All samples were probed for the expression of $\beta$-ACTIN; this was a minimum entry criterion for inclusion in the study. Approximately $10 \%$ of embryo samples did not express $\beta$-ACTIN and were discarded with no further analysis.

\section{Method of analysis}

Because of the scarcity of the human embryo material, we opted for a + or - scoring system indicating that signal was or was not detected after 40 cycles of PCR with gene-specific primers. Absence of signal after 40 cycles of amplification indicates that the gene is very unlikely to be expressed and, not withstanding carryover of maternal protein, may not be important at the stage indicated. Presence of definitive signal is indicative of gene expression, with potential translation and function. If expressed in rare cases (say one or two out of six blastocysts), we would conclude that this gene is not normally expressed and the presence of transcript may reflect a somewhat advanced developmental state (particularly for genes expressed normally at the late blastocyst) or as a result of a particular genetic state or environmental cue during the culture. An example of such an environmental cue might include stimulation by GFs present in the culture medium (see the Discussion section). If a gene is almost always detected except in a few blastocysts (say one in six or so), we would

Table 5 Growth factor study gene-specific amplification primers.

\begin{tabular}{|c|c|c|c|c|c|}
\hline Target gene & Primer pair sequences $\left(5^{\prime}-3^{\prime}\right)$ & $\begin{array}{l}\text { Accession } \\
\text { number }\end{array}$ & $\begin{array}{l}\text { Position in } \\
\text { sequence }\end{array}$ & $\begin{array}{c}\text { Fragment } \\
\text { size }(b p)\end{array}$ & $\begin{array}{l}\text { Annealing } \\
\text { temp }\left({ }^{\circ} \mathrm{C}\right)\end{array}$ \\
\hline \multirow[t]{2}{*}{$\beta-A C T I N$} & GACAGCAGTCGGTTGGACC & M10277 & $3163-3179$ & 387 & 62 \\
\hline & CAGGTAAGCCСTGGCTGC & & $3549-3532$ & & \\
\hline \multirow[t]{2}{*}{ OСТ3В/4 } & GTCTССTTTCTCAGGGGGAC & Z11899 & $722-741$ & 265 & 62 \\
\hline & САAAAACCСТGGCACAAACT & & $986-967$ & & \\
\hline \multirow[t]{2}{*}{ SOX2 } & CATGTCCCAGCACTACCAGA & XM_300854 & $1312-1331$ & 178 & 62 \\
\hline & GGGTTTTCTCCATGCTGTTT & & $1489-1470$ & & \\
\hline \multirow[t]{2}{*}{ NANOG } & CCGTTTTTGGCTCTGTTTTG & NM_024865 & $1907-1927$ & 187 & 62 \\
\hline & TTCACCGAGTGTTTCGATGA & & 2074-2094 & & \\
\hline \multirow[t]{2}{*}{ FOXD3 } & GCAGAAGAAGCTGACССTGA & NM_012183 & $471-491$ & 308 & 62 \\
\hline & CTGTAAGCGCCGAAGCTCT & & $760-779$ & & \\
\hline \multirow[t]{2}{*}{ TBN (Taube Nuss) } & GCAGAGTCCAGTCCAAAAGC & BC033728 & $588-607$ & 171 & 62 \\
\hline & GAGACAGGGTCTTGCTCTGC & & $758-738$ & & \\
\hline \multirow[t]{2}{*}{ TEF4 } & GAACCСTTTCTGTGCAGGAG & NM_003598 & $1922-1941$ & 197 & 62 \\
\hline & ACTTTGAGAGGGGAGGAAGG & & 2118-2099 & & \\
\hline \multirow[t]{2}{*}{ EIF4C } & ACCATGATTGCTGCTTTTCC & L18960 & 909-928 & 293 & 60 \\
\hline & TGTTTACGGTGGCAAAATACG & & $1201-1181$ & & \\
\hline \multirow[t]{2}{*}{$C D \times 2$} & CTGGCAGAAGCATTGCСT & NM_001265 & $1490-1508$ & 214 & 62 \\
\hline & TTTCCTGGTCTGGGAAGG & & $1686-1704$ & & \\
\hline \multirow[t]{2}{*}{ HASH2 Achaete-scute-like 2 (Mash2) } & CACATTAACTTGAGCTGCTGGA & AF442769 & $3088-3109$ & 88 & 57 \\
\hline & СTTTATTACGCCCCAGGTCA & & $3175-3156$ & & \\
\hline \multirow[t]{2}{*}{ EOMES } & TCAGACATCCCATGCCСТ & NM_005442 & $1665-1682$ & 263 & 60 \\
\hline & TTCGCTTACAAGCACTGGTG & & $1927-1908$ & & \\
\hline \multirow[t]{2}{*}{ GATA6 } & TGCTGGAAAAATTGCAACAA & X95701 & $3013-3032$ & 117 & 62 \\
\hline & CAACCTGCCTGTGGGTTAGT & & $3129-3110$ & & \\
\hline \multirow[t]{2}{*}{ DSC2 } & CACAAGCATGCCCAAGACTA & X56807 & $2625-2644$ & 203 & 62 \\
\hline & AAGCCACTGGCTTTCAGAGA & & $2827-2808$ & & \\
\hline \multirow[t]{2}{*}{ LIFR } & CAATTGCTTGGTGAGCTGTG & NM_002310 & $4659-4678$ & 154 & 62 \\
\hline & CTGAGGGCAGGGAAAATACA & & $4812-4793$ & & \\
\hline \multirow[t]{2}{*}{$E R B B 1$} & TCCGCAAGTGTAAGAAGTGC & NM_005228 & $1134-1153$ & 202 & 64 \\
\hline & TGTGGATCCAGAGGAGGAGT & & $1335-1316$ & & \\
\hline \multirow[t]{2}{*}{$E R B B 4$} & CAATATGGAAGCAACCAGCA & L07868 & $5102-5121$ & 172 & 64 \\
\hline & CTTGCGTAGCAAAGGTGACA & & $5273-5254$ & & \\
\hline
\end{tabular}


conclude that this gene is normally expressed, may play a function at the time analysed and that embryos that do not express may be deficient in some way.

\section{Immunocytochemistry}

PFA-fixed embryos were washed through PBS supplemented with $4 \mathrm{mg} / \mathrm{ml}$ IgG-free BSA (PBS/BSA; Stratech, Suffolk, UK). Embryos were permeabilised in $0.01 \%$ Triton X-100 in PBS/BSA for $5 \mathrm{~min}$, washed and transferred to a $25 \mu \mathrm{l}$ drop of primary antibody for $1 \mathrm{~h}$ under oil (anti-OCT3B/4: mouse monoclonal, BD 1:250 dilution: SOX2: rabbit polyclonal, Abcam 1:500 dilution; anti-NANOG: Goat $\operatorname{lgG}, \mathrm{R}+\mathrm{D}$ 1: 10 dilution). Rabbit antibodies were pre-adsorbed with keratin prior to use (Kimber et al. 1994). Embryos were washed and incubated in an appropriate secondary antibody (Molecular Probes, Invitrogen) and after further washing mounted in VECTASHIELD-containing 4,6-diaminidino-2-phenylindole hydrochloride (DAPI; Vector Labs, Peterborough, UK) prior to visualisation by confocal microscopy. Controls were incubated with normal rabbit serum or mouse IgG in place of primary antibodies. Test and control images were collected using identical confocal settings and manipulated identically.

\section{Acknowledgements}

We thank the MRC, the NHS NorthWest Region and the Central Manchester NHS Trust for funding. We are grateful to Maria Keramari for the SOX2 staining and to Robert Fernandez, Bioimaging Facility, University of Manchester for assistance with confocal microscopy. We would also like to thank couples undergoing IVF treatment who donated their embryos to this project. The authors declare that there is no conflict of interest that would prejudice the impartiality of this scientific work.

\section{References}

Abdel-Rahman B, Fiddler M, Rappolee D \& Pergament E 1995 Expression of transcription regulating genes in human preimplantation embryos. Human Reproduction 10 2787-2792.

Adjaye J, Huntriss J, Herwig R, BenKahla A, Brink TC, Wierling C, Hultschig C, Groth D, Yaspo ML, Picton HM et al. 2005 Primary differentiation in the human blastocyst: comparative molecular portraits of inner cell mass and trophectoderm cells. Stem Cells 23 1514-1525.

Al-Taher A, Bashein A, Nolan T, Hollingsworth M \& Brady G 2000 Global cDNA amplification combined with real-time RT-PCR: accurate quantification of multiple human potassium channel genes at the single cell level. Yeast 17 201-210.

Ambrosetti DC, Scholer HR, Dailey L \& Basilico C 2000 Modulation of the activity of multiple transcriptional activation domains by the DNA binding domains mediates the synergistic action of Sox 2 and Oct- 3 on the fibroblast growth factor-4 enhancer. Journal of Biological Chemistry 275 23387-23397.

Avilion AA, Nicolis SK, Pevny LH, Perez L, Vivian N \& Lovell-Badge R 2003 Multipotent cell lineages in early mouse development depend on SOX2 function. Genes and Development 17 126-140.

Bhattacharya B, Miura T, Brandenberger R, Mejido J, Luo Y, Yang AX, Joshi BH, Ginis I, Thies RS, Amit M et al. 2004 Gene expression in human embryonic stem cell lines: unique molecular signature. Blood 103 2956-2964.

Bloor DJ, Metcalfe AD, Rutherford A, Brison DR \& Kimber SJ 2002 Expression of cell adhesion molecules during human preimplantation embryo development. Molecular Human Reproduction 8 237-245.
Bloor DJ, Wilson Y, Kibschull M, Traub O, Leese HJ, Winterhager E \& Kimber SJ 2004 Expression of connexins in human preimplantation embryos in vitro. Reproduction Biology and Endocrinology 22.

Boyer LA, Lee TI, Cole MF, Johnstone SE, Levine SS, Zucker JP, Guenther MG, Kumar RM, Murray HL, Jenner RG et al. 2005 Core transcriptional regulatory circuitry in human embryonic stem cells. Cell 122 947-956.

Brady G \& Iscove NN 1993 Construction of cDNA libraries from single cells. Methods in Enzymology 225 611-623.

Brady G, Billia F, Knox J, Hoang T, Kirsch IR, Voura EB, Hawley RG, Cumming R, Buchwald M \& Siminovitch K 1995 Analysis of gene expression in a complex differentiation hierarchy by global amplification of cDNA from single cells. Current Biology 5 909-922.

Braude P, Bolton V \& Moore S 1988 Human gene expression first occurs between the four- and eight-cell stages of preimplantation development. Nature 332 459-461.

Brison DR, Houghton FD, Falconer D, Roberts SA, Hawkhead J, Humpherson PG, Lieberman BA \& Leese HJ 2004 Identification of viable embryos in IVF by non-invasive measurement of amino acid turnover. Human Reproduction 19 2319-2324.

Buehr M, Nichols J, Stenhouse F, Mountford P, Greenhalgh CJ, Kantachuvesiri S, Brooker G, Mullins J \& Smith AG 2003 Rapid loss of Oct- 4 and pluripotency in cultured rodent blastocysts and derivative cell lines. Biology of Reproduction 68 222-229.

Byrne AT, Southgate J, Brison DR \& Leese HJ 2002 Effects of insulin-like growth factors I and II on tumour-necrosis-factor-alpha-induced apoptosis in early murine embryos. Reproduction, Fertility, and Development 14 79-83.

Cauffman G, Van de Velde H, Liebaers I \& Van Steirteghem A 2005 Oct-4 $\mathrm{mRNA}$ and protein expression during human preimplantation development. Molecular Human Reproduction 11 173-181.

Chambers I, Colby D, Robertson M, Nichols J, Lee S, Tweedie S \& Smith A 2003 Functional expression cloning of Nanog, a pluripotency sustaining factor in embryonic stem cells. Cell 113 643-655.

Chobotova K, Spyropoulou I, Carver J, Manek S, Heath JK, Gullick WJ, Barlow DH, Sargent IL \& Mardon HJ 2002 Heparin-binding epidermal growth factor and its receptor ErbB4 mediate implantation of the human blastocyst. Mechanisms of Development 119 137-144.

Cross JC 2000 Genetic insights into trophoblast differentiation and placental morphogenesis. Seminars in Cell and Developmental Biology 11 105-113.

Das SK, Wang XN, Paria BC, Damm D, Abraham JA, Klagsbrun M, Andrews GK \& Dey SK 1994 Heparin-binding EGF-like growth factor gene is induced in the mouse uterus temporally by the blastocyst solely at the site of its apposition: a possible ligand for interaction with blastocyst EGF-receptor in implantation. Development 120 1071-1083.

Dobson AT, Raja R, Abeyta MJ, Taylor T, Shen S, Haqq C \& Pera RA 2004 The unique transcriptome through day 3 of human preimplantation development. Human Molecular Genetics 13 1461-1470.

Dunglison GF, Barlow DH \& Sargent IL 1996 Leukaemia inhibitory factor significantly enhances the blastocyst formation rates of human embryos cultured in serum-free medium. Human Reproduction 11 191-196.

Ghassemifar MR, Eckert JJ, Houghton FD, Picton HM, Leese HJ \& Fleming TP 2003 Gene expression regulating epithelial intercellular junction biogenesis during human blastocyst development in vitro. Molecular Human Reproduction 9 245-252.

Goto T, Jones GM, Lolatgis N, Pera MF, Trounson AO \& Monk M 2002 Identification and characterisation of known and novel transcripts expressed during the final stages of human oocyte maturation. Molecular Reproduction and Development 62 13-28.

Graham DR, Overbeek PA \& Ash JD 2005 Leukemia inhibitory factor blocks expression of $\mathrm{Crx}$ and $\mathrm{Nrl}$ transcription factors to inhibit photoreceptor differentiation. Investigative Ophthalmology \& Visual Science 46 2601-2610.

Guo Y, Costa R, Ramsey H, Starnes T, Vance G, Robertson K, Kelley M, Reinbold R, Scholer H \& Hromas R 2002 The embryonic stem cell transcription factors Oct- 4 and FoxD3 interact to regulate endodermalspecific promoter expression. PNAS 99 3663-3667.

Hanna LA, Foreman RK, Tarasenko IA, Kessler DS \& Labosky PA 2002 Requirement for Foxd3 in maintaining pluripotent cells of the early mouse embryo. Genes and Development 16 2650-2661.

Hansis C, Grifo JA \& Krey LC 2000 Oct-4 expression in inner cell mass and trophectoderm of human blastocysts. Molecular Human Reproduction $\mathbf{6}$ 999-1004. 
Hansis C, Tang YX, Grifo JA \& Krey LC 2001 Analysis of Oct-4 expression and ploidy in individual human blastomeres. Molecular Human Reproduction 7 155-161.

Hardy K \& Spanos S 2002 Growth factor expression and function in the human and mouse preimplantation embryo. Journal of Endocrinology $172221-236$.

Hardy K, Wright C, Rice S, Tachataki M, Roberts R, Morgan D, Spanos S \& Taylor D 2002 Future developments in assisted reproduction in humans. Reproduction 123 171-183.

Harvey MB \& Kaye PL 1991 Mouse blastocysts respond metabolically to short-term stimulation by insulin and IGF-1 through the insulin receptor. Molecular Reproduction and Development 29 253-258.

Harvey MB \& Kaye PL 1992 Insulin-like growth factor-1 stimulates growth of mouse preimplantation embryos in vitro. Molecular Reproduction and Development 31 195-199.

Hatano SY, Tada M, Kimura H, Yamaguchi S, Kono T, Nakano T, Suemori H, Nakatsuji N \& Tada T 2005 Pluripotential competence of cells associated with Nanog activity. Mechanisms of Development 122 67-79.

Houghton FD, Hawkhead JA, Humpherson PG, Hogg JE, Balen AH, Rutherford AJ \& Leese HJ 2002 Non-invasive amino acid turnover predicts human embryo developmental capacity. Human Reproduction 17 999-1005.

Humphrey RK, Beattie GM, Lopez AD, Bucay N, King CC, Firpo MT, RoseJohn S \& Hayek A 2004 Maintenance of pluripotency in human embryonic stem cells is STAT3 independent. Stem Cells 22 522-530.

Huntriss J, Gosden R, Hinkins M, Oliver B, Miller D, Rutherford AJ \& Picton HM 2002 Isolation, characterization and expression of the human factor in the germline alpha (FIGLA) gene in ovarian follicles and oocytes. Molecular Human Reproduction 8 1087-1095.

Iscove NN, Barbara M, Gu M, Gibson M, Modi C \& Winegarden N 2002 Representation is faithfully preserved in global cDNA amplified exponentially from sub-picogram quantities of mRNA. Nature Biotechnology 20 940-943.

Jurisicova A \& Acton BM 2004 Deadly decisions: the role of genes regulating programmed cell death in human preimplantation embryo development. Reproduction 128 281-291.

Kaneko KJ \& DePamphilis ML 1998 Regulation of gene expression at the beginning of mammalian development and the TEAD family of transcription factors. Developmental Genetics 22 43-55.

Kaye PL, Bell KL, Beebe LF, Dunglison GF, Gardner HG \& Harvey MB 1992 Insulin and the insulin-like growth factors (IGFs) in preimplantation development. Reproduction, Fertility, and Development 4 373-386.

Kimber SJ 2005 Leukaemia inhibitory factor in implantation and uterine biology. Reproduction 130 131-145.

Kimber SJ, Bentley J, Ciemerych M, Moller CJ \& Bock E 1994 Expression of $\mathrm{N}-\mathrm{CAM}$ in fertilized pre- and periimplantation and parthenogenetically activated mouse embryos. European Journal of Cell Biology 63 102-113.

Knofler M, Meinhardt G, Bauer S, Loregger T, Vasicek R, Bloor DJ, Kimber SJ \& Husslein P 2002 Human Hand1 basic helix-loop-helix (bHLH) protein: extra-embryonic expression pattern, interaction partners and identification of its transcriptional repressor domains. Biochemical Journal 361 641-651.

Koutsourakis M, Langeveld A, Patient R, Beddington R \& Grosveld F 1999 The transcription factor GATA6 is essential for early extraembryonic development. Development 126 723-732.

Kuroda T, Tada M, Kubota H, Kimura H, Hatano SY, Suemori H, Nakatsuji N \& Tada T 2005 Octamer and Sox elements are required for transcriptional cis regulation of Nanog gene expression. Molecular and Cellular Biology 25 2475-2485.

Li L, Arman E, Ekblom P, Edgar D, Murray P \& Lonai P 2004 Distinct GATA6- and laminin-dependent mechanisms regulate endodermal and ectodermal embryonic stem cell fates. Development 131 5277-5286.

Li X, Kato Y \& Tsunoda Y 2005 Comparative analysis of developmentrelated gene expression in mouse preimplantation embryos with different developmental potential. Molecular Reproduction and Development 72 152-160.

Lighten AD, Moore GE, Winston RM \& Hardy K 1998 Routine addition of human insulin-like growth factor-I ligand could benefit clinical in vitro fertilization culture. Human Reproduction 13 3144-3150.

Liu Z \& Armant DR 2004 Lysophosphatidic acid regulates murine blastocyst development by transactivation of receptors for heparin-binding EGF-like growth factor. Experimental Cell Research 296 317-326.
Liu J, Rich CB, Buczek-Thomas JA, Nugent MA, Panchenko MP \& Foster JA 2003 Heparin-binding EGF-like growth factor regulates elastin and FGF-2 expression in pulmonary fibroblasts. American Journal of Physiology. Lung Cellular and Molecular Physiology 285 L1106-L1115.

Martin KL, Barlow DH \& Sargent IL 1998 Heparin-binding epidermal growth factor significantly improves human blastocyst development and hatching in serum-free medium. Human Reproduction 13 1645-1652.

Masui S, Nakatake Y, Toyooka Y, Shimosato D, Yagi R, Takahashi K, Okochi H, Okuda A, Matoba R, Sharov AA et al. 2007 Pluripotency governed by Sox2 via regulation of Oct3/4 expression in mouse embryonic stem cells. Nature Cell Biology 9 625-635.

Metcalfe AD, Bloor DJ, Lieberman BA, Kimber SJ \& Brison DR 2003 Amplification of representative cDNA pools from single human oocytes and pronucleate embryos. Molecular Reproduction and Development 65 1-8.

Metcalfe AD, Hunter HR, Bloor DJ, Lieberman BA, Picton HM, Leese HJ, Kimber SJ \& Brison DR 2004 Expression of 11 members of the BCL-2 family of apoptosis regulatory molecules during human preimplantation embryo development and fragmentation. Molecular Reproduction and Development 68 35-50.

Mitalipov SM, Kuo HC, Hennebold JD \& Wolf DP 2003 Oct-4 expression in pluripotent cells of the rhesus monkey. Biology of Reproduction 69 1785-1792.

Mitsui K, Tokuzawa Y, Itoh H, Segawa K, Murakami M, Takahashi K, Maruyama M, Maeda M \& Yamanaka S 2003 The homeoprotein Nanog is required for maintenance of pluripotency in mouse epiblast and ES cells. Cell 113 631-642.

Neilson L, Andalibi A, Kang D, Coutifaris C, Strauss JF 3rd, Stanton JA \& Green DP 2000 Molecular phenotype of the human oocyte by PCRSAGE. Genomics 63 13-24.

Nishimoto M, Fukushima A, Okuda A \& Muramatsu M 1999 The gene for the embryonic stem cell coactivator UTF1 carries a regulatory element which selectively interacts with a complex composed of Oct-3/4 and SOX2. Molecular and Cellular Biology 19 5453-5465.

Niwa H, Miyazaki J \& Smith AG 2000 Quantitative expression of Oct-3/4 defines differentiation, dedifferentiation or self-renewal of ES cells. Nature Genetics 24 372-376.

Niwa H, Toyooka Y, Shimosato D, Strumpf D, Takahashi K, Yagi R \& Rossant J 2005 Interaction between Oct3/4 and Cdx2 determines trophectoderm differentiation. Cell 123 917-929.

Nunez C, Bashein AM, Brunet CL, Hoyland JA, Freemont AJ, Buckle AM, Murphy C, Cross MA, Lucas G, Bostock VJ et al. 2000 Expression of the imprinted tumour-suppressor gene $\mathrm{H} 19$ is tightly regulated during normal haematopoiesis and is reduced in haematopoietic precursors of patients with the myeloproliferative disease polycythaemia vera. Journal of Pathology 190 61-68.

Okumura-Nakanishi S, Saito M, Niwa H \& Ishikawa F 2005 Oct-3/4 and Sox2 regulate Oct-3/4 gene in embryonic stem cells. Journal of Biological Chemistry 280 5307-5317.

Palmieri SL, Peter W, Hess H \& Scholer HR 1994 Oct-4 transcription factor is differentially expressed in the mouse embryo during establishment of the first two extraembryonic cell lineages involved in implantation. Developmental Biology 166 259-267.

Paria BC, Elenius K, Klagsbrun M \& Dey SK 1999 Heparin-binding EGF-like growth factor interacts with mouse blastocysts independently of ErbB1: a possible role for heparan sulfate proteoglycans and ErbB4 in blastocyst implantation. Development 126 1997-2005.

Pesce M \& Scholer HR 2001 Oct-4: gatekeeper in the beginnings of mammalian development. Stem Cells 19 271-278.

Raab G, Kover K, Paria BC, Dey SK, Ezzell RM \& Klagsbrun M 1996 Mouse preimplantation blastocysts adhere to cells expressing the transmembrane form of heparin-binding EGF-like growth factor. Development 122 637-645.

Ralston A \& Rossant J 2005 Genetic regulation of stem cell origins in the mouse embryo. Clinical Genetics 68 106-112.

Richards M, Tan SP, Tan JH, Chan WK \& Bongso A 2004 The transcriptome profile of human embryonic stem cells as defined by SAGE. Stem Cells $\mathbf{2 2}$ 51-64.

Rodda DJ, Chew JL, Lim LH, Loh YH, Wang B, Ng HH \& Robson P 2005 Transcriptional regulation of nanog by OCT4 and SOX2. Journal of Biological Chemistry $28024731-24737$. 
Rosner MH, Vigano MA, Ozato K, Timmons PM, Poirier F, Rigby PW \& Staudt LM 1990 A POU-domain transcription factor in early stem cells and germ cells of the mammalian embryo. Nature 345 686-692.

Sarfstein R \& Werner H 2006 The WT1 Wilms' tumor suppressor gene is a downstream target for insulin-like growth factor-I (IGF-I) action in PC12 cells. Journal of Neurochemistry 99 818-826.

Schafer-Somi S 2003 Cytokines during early pregnancy of mammals: a review. Animal Reproduction Science 75 73-94.

Sekkai D, Gruel G, Herry M, Moucadel V, Constantinescu SN, Albagli O, Tronik-Le Roux D, Vainchenker W \& Bennaceur-Griscelli A 2005 Microarray analysis of LIF/Stat3 transcriptional targets in embryonic stem cells. Stem Cells 23 1634-1642.

Sharkey AM, Dellow K, Blayney M, Macnamee M, Charnock-Jones S \& Smith SK 1995 Stage-specific expression of cytokine and receptor messenger ribonucleic acids in human preimplantation embryos. Biology of Reproduction 53 974-981.

Sherwin JR, Freeman TC, Stephens RJ, Kimber S, Smith AG, Chambers I, Smith SK \& Sharkey AM 2004 Identification of genes regulated by leukemia-inhibitory factor in the mouse uterus at the time of implantation. Molecular Endocrinology 18 2185-2195.

Sjoblom C, Roberts CT, Wikland M \& Robertson SA 2005 Granulocytemacrophage colony-stimulating factor alleviates adverse consequences of embryo culture on fetal growth trajectory and placental morphogenesis. Endocrinology 146 2142-2153.

Smith AG, Heath JK, Donaldson DD, Wong GG, Moreau J, Stahl M \& Rogers D 1988 Inhibition of pluripotential embryonic stem cell differentiation by purified polypeptides. Nature 336 688-690.

De Sousa PA, Watson AJ \& Schultz RM 1998 Transient expression of a translation initiation factor is conservatively associated with embryonic gene activation in murine and bovine embryos. Biology of Reproduction 59 969-977.

Stewart CL, Kaspar P, Brunet LJ, Bhatt H, Gadi I, Kontgen F \& Abbondanzo SJ 1992 Blastocyst implantation depends on maternal expression of leukaemia inhibitory factor. Nature 359 76-79.
Strumpf D, Mao CA, Yamanaka Y, Ralston A, Chawengsaksophak K, Beck F \& Rossant J $2005 \mathrm{Cdx} 2$ is required for correct cell fate specification and differentiation of trophectoderm in the mouse blastocyst. Development 132 2093-2102.

Takahashi K, Tanabe K, Ohnuki M, Narita M, Ichisaka T, Tomoda K \& Yamanaka S 2007 Induction of pluripotent stem cells from adult human fibroblasts by defined factors. Cell 131 861-872.

Tan Y, Li M, Cox S, Davis MK, Tawfik O, Paria BC \& Das SK 2004 HBEGF directs stromal cell polyploidy and decidualization via cyclin D3 during implantation. Developmental Biology 265 181-195.

Tomioka M, Nishimoto M, Miyagi S, Katayanagi T, Fukui N, Niwa H, Muramatsu M \& Okuda A 2002 Identification of SOX2 regulatory region which is under the control of Oct-3/4-SOX2 complex. Nucleic Acids Research 30 3202-3213.

Voss AK, Thomas T, Petrou P, Anastassiadis K, Scholer H \& Gruss P 2000 Taube nuss is a novel gene essential for the survival of pluripotent cells of early mouse embryos. Development 127 5449-5461.

Wang J, Mayernik L, Schultz JF \& Armant DR 2000 Acceleration of trophoblast differentiation by heparin-binding EGF-like growth factor is dependent on the stage-specific activation of calcium influx by ErbB receptors in developing mouse blastocysts. Development 127 33-44.

Willems E, Mateizel I, Kemp C, Cauffman G, Sermon K \& Leyns L 2006 Selection of reference genes in mouse embryos and in differentiating human and mouse ES cells. International Journal of Developmental Biology 50 627-635.

Zhang P, Kerkelä E, Skottman H, Levkov L, Kivinen K, Lahesmaa R, Hovatta O \& Kere J 2007 Distinct sets of developmentally regulated genes that are expressed by human oocytes and human embryonic stem cells. Fertility and Sterility 87 677-690.

Received 2 August 2007

First decision 11 September 2007

Revised manuscript received 8 January 2008

Accepted 23 January 2008 